\title{
CHARACTERIZING THERMAL MATURITY AND HYDROCARBON POTENTIAL OF SOURCE ROCK USING ROCK-EVAL 6 PYROLYSIS TECHNIQUE
}

\author{
Benedict Aduomahor \\ Department of Geology \\ University of Benin, Nigeria.
}

\author{
Smart O. Osarenogowu \\ Department of Geology \\ University of Benin, Nigeria.
}

\author{
Department of Geology, \\ Federal University of Technology, Owerri, Nigeria
}

Onyekachi Ibezim

\begin{abstract}
Organic geochemical evaluation of source rock within a petroleum system is important considering its role as the source of hydrocarbon. Subsurface samples at depth of $2361 \mathrm{~m}$ (outer shelf) and $2613 \mathrm{~m}$ (lower slope) from Pologbene-1 Well located within the northern delta depobelt were analysed using Rock-Eval pyrolysis analytical technique. This technique involves the temperature programmed heating of samples in an inert environment. Inference was drawn from Rock-Eval geochemical parameters, which include S1, S2, TOC, and $\mathrm{T}_{\max }$ Others are Hydrogen Index (HI), Oxygen Index (OI) and Production Index (PI). The results were compared with the inner shelf $(1716 \mathrm{~m})$ and the upper slope $(2595 \mathrm{~m})$ of the same well. Two geochemical models were established: $\mathrm{HI} / \mathrm{OI}$ and $\mathrm{HI} / \mathrm{T}_{\max }$, for the outer shelf and upper slope source rock of Pologbene-1 Well. The two models were derived from $\mathrm{HI}$ values of 502 and 548 , OI value of 14 and 15 and $T_{\text {mas }}$ value of $429^{\circ} \mathrm{C}$ and $419^{\circ} \mathrm{C}$ (outer and upper slope respectively). The model indicate that the samples are oil and gas prone, are type II source rock containing type II kerogen. S1, S2 and TOC values of $7.96 \mathrm{mg} / \mathrm{g}, 328 \mathrm{mg} / \mathrm{g}$ and $65.36 \mathrm{wtpercentage}$ for outer shelf and $7.51 \mathrm{mg} / \mathrm{g}, 325 \mathrm{mg} / \mathrm{g}, 59.37$ percentage for upper slope respectively indicate good to excellent source capacity and high petroleum potential for Pologbene-1 Well.
\end{abstract}

Keywords - Organic geochemical evaluation; source rock, depositional environment; kerogen type; Niger Delta Basin

\section{INTRODUCTION}

The relationship between the occurrence of organic compound in sedimentary deposits and petroleum deposit has long been of interest. Studies of ancient sediments and rock provide insights into the origins and sources of oil petroleum geochemistry and the biochemical antecedents of life.

In petroleum geology, source rock refers to rock from which hydrocarbon have been generated or are capable of being generated. They are sedimentary rocks that are, or may become, or have been able to generate petroleum (Tissot et al. 1984). They are organic-rich sediments that may have been deposited in a variety of environments including deep water, marine, lacustrine and deltaic, and one of the necessary elements of a working petroleum system.

Various methods have been employed over time to determine the petroleum potential of source rock, their stages of thermal maturation, type and class of inherent kerogen. The generative source potential and the main product expelled at peak maturity is also of basic interest.

This study therefore seeks to determine the thermal maturity and petroleum generative potential of source rock in the northern delta depobelt of the Niger Delta Basin, using RockEval pyrolysis approach.

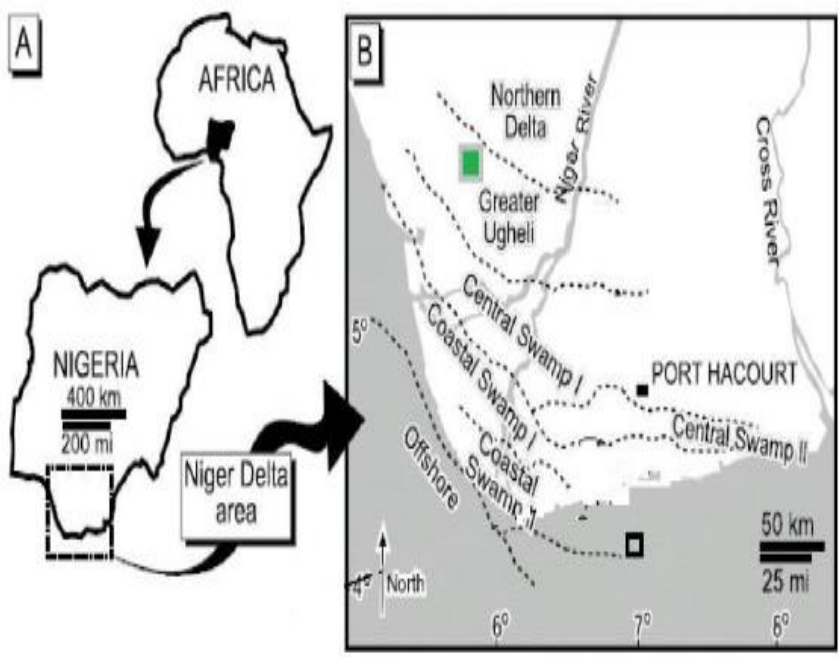

Figure 1: Map of study area

\section{MethodOLOGY}

The major method employed for this study is the Rock-Eval 6 pyrolysis, which aim is to identify the type and maturity of organic matter and to detect petroleum potential in sediments. 


\section{International Journal of Engineering Applied Sciences and Technology, 2020 \\ Vol. 4, Issue 11, ISSN No. 2455-2143, Pages 533-536 \\ Published Online March 2020 in IJEAST (http://www.ijeast.com)}

Subsurface samples at depth of $2361 \mathrm{~m}$ (outer shelf) and 2613m (lower slope) from Pologbene-1 Well were analysed using Rock-Eval pyrolysis analytical technique, which involves the temperature programmed heating of samples in an inert environment.

\section{Procedures for Determining Direct Measurements}

The parameters, which are a result of direct measurement from the Rock-Eval pyrolysis procedure, include S1, S2, S3 and Tmax.

$25 \mathrm{~g}$ of the sample is prepared. It is crushed, disaggregated, and then passed through a $25 \mathrm{um}$ sieve. The samples are placed in a temperature programmed muffled furnace, which is built to model an inert environment, an environment devoid of oxygen. The temperature is programmed at $100^{\circ} \mathrm{c}$ with a steady rise of $25^{\circ} \mathrm{C}$ per minute, between $300-350^{\circ} \mathrm{C}$, the first reading for $\mathrm{S} 1$ is taken. $\mathrm{S} 1$ represent the already generated hydrocarbon (oil and gas) in the rock.

Trapped $\mathrm{CO} 2$ in the sample starts evolving when the temperature is increased slightly. At temperature range of 350 $-390^{\circ} \mathrm{C}$ when $\mathrm{CO} 2$ evolves, $\mathrm{S} 3$ is measured. S3 is the amount of $\mathrm{CO} 2$ produced during pyrolysis of kerogen. It represents the amount of oxygen in the sample. With increase temperature of pyrolysis, S2 is measured within a temperature range of 300$600^{\circ} \mathrm{C}$. The maximum temperature, $\mathrm{T}_{\max }$ is the temperature of maximum release of hydrocarbon during Rock- Eval pyrolysis. It occurs at top of the $\mathrm{S} 2$ peak between the temperature of $300-600^{\circ} \mathrm{C}$. Above $650^{\circ} \mathrm{C}$ the value of $\mathrm{S} 4$ is measured. $\mathrm{CO}$ and $\mathrm{CO} 2$ are both component of $\mathrm{S} 4$.

S1: This is the already generated oil in the rock. These are the free hydrocarbons (oil and gas) already present in the sample, and they are distilled out of the sample at initial heating of the sample to a temperature of $350^{\circ} \mathrm{C}$, free hydrocarbon increases with depth. These values may be anomalously high from migration and contamination by drilling fluids and mud.

$\mathrm{S} 1=1.0 \mathrm{mg} \mathrm{HC} / \mathrm{g}$ dry rock-Minimum value for good source rocks.

S2: The amount of hydrocarbon generated through thermal cracking of nonvolatile organic matter (kerogen) when the sample temperature is increased to $550^{\circ} \mathrm{c}$. S2 is an indication of the quantity of hydrocarbon that parameter normally deceases with burial depth $>1 \mathrm{~km}$.

$\mathrm{S} 2>=5.0 \mathrm{mg} \mathrm{HC} / \mathrm{dry}$ rock - Minimum value for good source rocks

S3: The trapped $\mathrm{CO} 2$ released during pyrolysis up to a temperature of $390^{\circ} \mathrm{c}$. This value is proportional to the Oxygen present in the kerogen. Carbonate rock may increase S3 values.

Maximum Temperature $\left(\operatorname{Tmax}^{0} \boldsymbol{C}\right)$ : Defines the temperature at maximum release of hydrocarbon occurs during Rock- Eval pyrolysis. This occurs at the top of the S2 peak. T max is a maturation parameter that is kerogen - dependent.

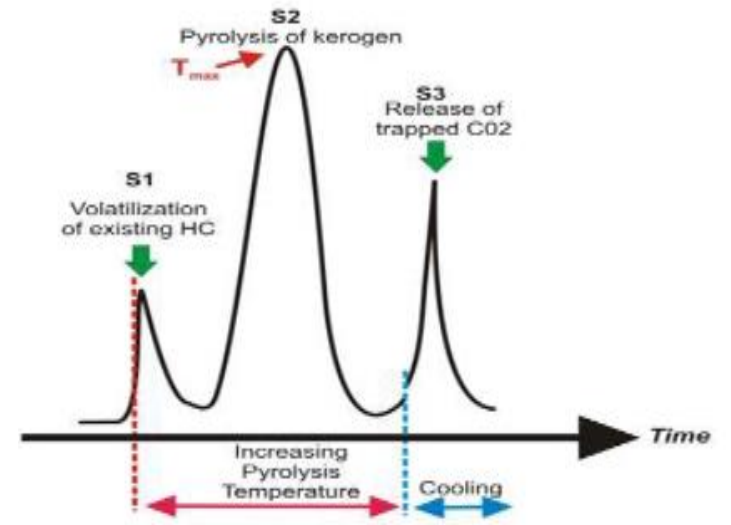

Figure 2: Model showing parameters derived from Roc Eval Pyrolysis

\section{Determination of Derived Measurement}

Hydrogen Index $(\boldsymbol{H I})=(\mathrm{S} 2 / \mathrm{TOC}) * 100$

The ratio of $\mathrm{S} 2$ hydrogen (in $\mathrm{mg} \mathrm{HC} / \mathrm{g}$ dry rock) to total organic carbon (TOC) in grams. The hydrogen index is a measure of the hydrogen richness of the source rock, and when the kerogen type is known, it can be used to estimate the thermal maturity of the rock. When plotted against the oxygen index (OI), the $\mathrm{HI}$ can be used to provide a good assessment of the petroleum generative potential in a source rock (Peters and Moldowan, 1993).

Oxygen Index $(\mathrm{OI})=(\mathrm{S} 3 / \mathrm{TOC}) * 100$

The ratio of S3 (mg CO2/g dry rock) to TOC (in grams). The parameter measures the oxygen richness of a source rock and can be used in conjunction with the hydrogen index to estimate the quality and thermal maturity of source rocks. This index is unreliable in rocks with high carbonate content. High OI value $(>50 \mathrm{mg} / \mathrm{g})$ are characteristic of immature hydrogens. Production Index $(P I)=\mathrm{SI} / \mathrm{S} 1+\mathrm{S} 2)$.

The production index is the ratio of already generated hydrocarbon to potential hydrocarbons. Low ratios indicate either immaturity or extreme post mature organic matter. High ratios indicate the mature stage or contamination by migrated hydrocarbons or drilling additives. The PI increases steady with depth and associated hydrocarbon generation.

\section{Determination of Total Organic Carbon (TOC)}

To determine the values of TOC, the samples are pyrolysed to temperature greater than $850^{\circ} \mathrm{c}$ in an oven. A process known as oxidation. This gives the organic carbon evolved above this temperature.

Determination of Total Percentage of Hydrocarbon (TPH)

$10 \mathrm{~g}$ of the sample is placed on top a glass chromatographic column packed with activated silica gel. $100 \mathrm{ml}$ of xylene is poured through the column. Silica gel attracts and absorbs aromatics. Because of this strong through the column. The fraction of aromatics and non-aromatics are weighed and measured as $\mathrm{A}$ and $\mathrm{B}$

$\mathrm{A}=$ weight of aromatics recovered

$\mathrm{B}=$ weight of non-aromatics recovered

Aromatic fraction $(\mathrm{wt} \%)=(\mathrm{A} /(\mathrm{A}=\mathrm{B})) * 100$

Non-aromatic fraction $(\mathrm{wt} \%)=(\mathrm{B} /(\mathrm{A}+\mathrm{B})) * 100$ 


\section{International Journal of Engineering Applied Sciences and Technology, 2020 \\ Vol. 4, Issue 11, ISSN No. 2455-2143, Pages 533-536 \\ Published Online March 2020 in IJEAST (http://www.ijeast.com)}

Materials used for the analysis include spectrophotometer, temperature-programmed muffled furnace, carthometer, cuvette, mortar and pestle, chromatographic glass column.

\section{RESULT}

Inference from Hydrogen Index (HI) and HI/OI Geochemical Model for Pologbene-1

The hydrogen index (HI) gives an indication of the hydrogen richness of source rocks. Hydrogen rich samples have higher hydrocarbon production potential. The hydrogen index (HI) also gives insight to the type of kerogen present in the sample. (Peters and Cassa, 1991).

Comparing result gotten from Rock-Eval pyrolysis with standard range by Peters and Cassa in table 6 shows that the samples at this depth are of type II source rock. In addition, a cross plot of $\mathrm{HI} / \mathrm{T}_{\max }$ on a modified Van Krevelen plots into the kerogen type II region thus confirming the same inference from HI. The sample could be either of the several type of type II kerogen which include exinite (formed from the casings of pollen and spores), cutinite (formed from terrestrial plant cuticle), resinite (formed from terrestrial plant resins and animal decomposition resins) and liptinite (white are formed from terrestrial plants lipids and marine algae). Type II kerogen are formed from lipids deposited in a reducing condition. It can also be inferred that the sample have Hydrogen to Carbon ratio (H:C) of $<1.25$ and Oxygen to carbon ratio $(\mathrm{O}: \mathrm{C})$ ranging between 0.03 to 0.58 which are typical of type II kerogen source rocks. They all have great tendencies to produce petroleum.

Table 1: Showing Result from Rock-Eval pyrolysis (direct and derived measurement)

\begin{tabular}{|c|c|c|c|c|c|c|}
\hline $\begin{array}{c}\text { DEPOSITIONAL } \\
\text { ENVIRONMENT }\end{array}$ & DEPTH (m) & $\begin{array}{c}\text { S1 } \\
(\mathbf{m g} / \mathbf{g})\end{array}$ & $\begin{array}{c}\mathbf{S 2} \\
(\mathbf{m g} / \mathbf{g})\end{array}$ & $\begin{array}{c}\mathbf{S 3} \\
(\mathbf{m g} / \mathbf{g})\end{array}$ & $\begin{array}{c}\text { S4 } \\
(\mathbf{m g} / \mathbf{g})\end{array}$ & $\begin{array}{c}\text { Tmax } \\
(\mathbf{o c})\end{array}$ \\
\hline $\begin{array}{c}\text { Pologbene-1 Well } \\
\text { (Outer shelf) }\end{array}$ & 1716 & 8.81 & 271 & 4 & $0.58,0.31$ & 453 \\
\hline $\begin{array}{c}\text { Pologbene-1 Well } \\
\text { (Inner shelf) }\end{array}$ & 2361 & 7.96 & 328 & 9 & $0.58,0.13$ & 429 \\
\hline $\begin{array}{c}\text { Pologbene-1 Well } \\
\text { (Upper slope) }\end{array}$ & 2595 & 7.43 & 321 & 8 & $0.57,0.17$ & 419 \\
\hline $\begin{array}{c}\text { Pologbene-1 Well } \\
\text { (Lower slope) }\end{array}$ & 2613 & 7.51 & 325 & 9 & $0.56,0.18$ & 420 \\
\hline
\end{tabular}

\begin{tabular}{|c|c|c|c|c|c|c|}
\hline $\begin{array}{c}\text { DEPOSITIONAL } \\
\text { ENVIRONMENT }\end{array}$ & DEPTH(m) & $\begin{array}{c}\text { TOC (wt } \\
\mathbf{\%})\end{array}$ & $\begin{array}{c}\text { THC (wt } \\
\mathbf{\%})\end{array}$ & HI & OI & TPH (wt \%) \\
\hline $\begin{array}{c}\text { Pologbene-1 Well (Outer } \\
\text { shelf) }\end{array}$ & 1716 & 0.751 & 1797 & 361 & 5 & 71.9 \\
\hline $\begin{array}{c}\text { Pologbene-1 Well (Inner } \\
\text { shelf) }\end{array}$ & 2361 & 0.654 & 1576 & 502 & 14 & 63.1 \\
\hline $\begin{array}{c}\text { Pologbene-1 Well (Upper } \\
\text { slope) }\end{array}$ & 2595 & 0.602 & 1524 & 533 & 14 & 61.03 \\
\hline $\begin{array}{c}\text { Pologbene-1 Well (Lower } \\
\text { slope) }\end{array}$ & 2613 & 0.594 & 1504 & 548 & 15 & 60.24 \\
\hline
\end{tabular}

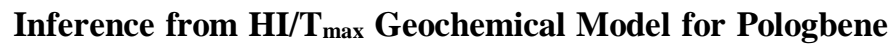
-1 WELL

This model was established by plotting value of $\mathrm{HI}$ from Rock-Eval against OI on a modified Van Krevelen diagram to deduce the type of source rock the analysed sample belong.

The cross-plot marker fell within the region of type II source rock on the geochemical model therefore, it can be inferred that the analysed samples are possibly type II source rocks. It therefore means that the analysed sample contains marine planktonic remains preserved under anoxic condition in a marine environment.

Type II source rocks produce both oil and gas when thermally cracked during deep burial.

\section{CONCLUSION}

Organic geochemical studies afford a holistic evaluation and characterization of source rocks and are useful in petroleum exploration. It also provides information needed to make maps of the richness, type and thermal maturity of a source rock. These maps are a necessary step towards determining the 


\section{International Journal of Engineering Applied Sciences and Technology, 2020 \\ Vol. 4, Issue 11, ISSN No. 2455-2143, Pages 533-536 \\ Published Online March 2020 in IJEAST (http://www.ijeast.com)}

stratigraphic and geographic extent of a pod of active source rock in a petroleum system and they are based on geochemical analysis of source rock sample from outcrop and wells.

From the geochemical evaluation of ditch cutting samples from Pologbene-1 well at depth of $2361 \mathrm{~m}$ (outer shelf) and $2613 \mathrm{~m}$ (lower shelf) and further comparison with results of similar studies on the same well at depth of $176 \mathrm{~m}$ (inner self) and 2595m (upper slope), it can be concluded that Pologbene1 well is oil and gas prone. This inference was drawn directly from individual parameter and an interplay or combination of parameters.

TOC, S1 and S2 geochemical parameter indicated samples that have good to excellent source capacity and excellent petroleum potential.

Tmax and Production Index (PI) value shows that the source rocks are immature. Thermally immature source rocks have been affected by diagenesis without any pronounced effect of temperature. Immature source rocks do not produce hydrocarbon.

Hydrogen Index (HI) and HI/OI geochemical model indicated kerogen type II for these samples while it was deduced from HI/OI geochemical model that the samples are type II source rock capable of producing a mixture of oil and gas.

Conclusively, it can therefore be said that the samples have the right quality (type) and quantity (amount) of organic matter with excellent source potential, but it is immature. However, at peak maturity the samples will generate a mixture of oil and gas.

\section{REFERENCE}

1. Agagu, O.K., and Ekweozor, C.M. (1982) 'Source Rock Characteristics of Senonian Shales in the Anambra Syncline, Southern Nigeria' in Journal of Mining and Geology, (pp 102 - 119)

2. Agagu, O. K., and Fayose, E. A. (1985): 'Stratigraphy and Sedimentation in the Santonian Anambra Basin of Eastern Nigeria' in Nig. Jour. Min. Geo. V221 and 222

3. Hunt, J.M. (1979). Petroleum Geochemisty and Geology: 2nd Ed. Freeman and Company: San Francisco

4. Kogbe, C. A. (1989). Geology of Nigeria, Second edition.

5. Ojo, O.J., Kolawole, A. U and Akande, S. O. (2001) 'Depositional Environments, Organic Richness and Petroleum Generating Potential of the Campanian to Maastrichtian Enugu Formation, Anambra Basin, Nigeria' in Nig. Jour. Min. Geo. Vol 431

6. Peters, K. E., and Moldowan, J.M. (1993) 'The Biomarker Guide: Interpreting Molecular Fossils in Petroleum and Ancient Sediment' Prentice Hall: Englewood.

7. Peters, K. E. and Cassa, M. R. (1994). 'Applied Source Rock Geochemistry. In: The Petroleum System-From Source to Trap' Magoon and Dow (editors)
8. Reijers, T.J.A. and Nwajide, C.S (1996). 'Selected Chapters in Geology, in SPDC of Nigeria Corporate Reprographic Services: Warri

9. Reijers, T.J.A, Petters S.W and Nwajide, C.S (1996) 'The Niger Delta Basin' African Basins, In Selley, R.C. (Ed.). Amsterdam Elserview, (pp 150-170)

10. Short, K.C and Stauble, A. D. (1965): 'Outline of Geology of Niger Delta' in AAPG Bulletin Vol 51 (pp761-779).

11. Tissot B., and Welte, D. H. (1984). Petroleum Formation and Occurrence. Springer-Verlag: New York.

12. Van Krevelen, D. W. (1961). Coal. Elsevieir: Amsterdam, Netherlands.

13. Weber, K.J (1987) 'Hydrocarbon Distribution Pattern in Nigeria Growth Fault Structures Controlled by Structural Style and Stratigraphy' Journal of. Petrol. Sci. and Engineering. Elsevier Science Publishers B.V. Amsterdam, Vol 8 (pp 1-12).

14. Whiteman A.J. (1982) 'Nigeria, Its Petroleum, Geology, Resources and Potential' in Graham and Trotman, London, 1982. 